\title{
Islamic Ethics, Human Rights and Migration
}

\author{
Khaled Abou El Fadl
}

I will begin by addressing the issue of migration first from a Muslim perspective. I will then comment about the international law that governs issues of migration, and then come back to what might be termed, "Islamic moral impulses" - what in my view is a tradition that could be developed, but which so far, has not.

Normative Impulses

Perhaps a good starting point would be the Qur'anic verse in Surat al-Isrä' (The Night's Journey) stating that "God dignified human beings and has facilitated to them mobility on earth and the seas, and bestowed bounties upon them and distinguished human beings over much of God's other creations (or creatures)." (Q. 17:70). I have always been struck by the discourse of this verse: the idea that mobility and travel-i.e. the ability to traverse earth and sea, and mobility and access in the form of travel - is perhaps a constituent element in human dignity; and in fact, that the denial of mobility detracts from our dignity as human beings. Mobility implies freedom, and in this context, the Quranic discourse can be understood to refer to the freedom to enjoy what God has created and made available to human beings. If human beings are denied the freedom of mobility, does this diminish human dignity? Note that it is not necessarily the actual movement that is necessary for human dignity but the freedom to do so. What is deprecating to dignity is the inability or more precisely, the denial of freedom of movement.

Added to the Qur'anic narrative found in Surat al-Isrä is the discourse of Surat al-Nis $\bar{a}$ ' (The Women), one that easily lends itself to the issue of migration. In Surat al-Nis $\vec{a}$, the Qur'an addresses those for whom the angels come to arrest their souls and are found in a state of inequity. Then, we have this intriguing inquiry from the Heavens asking what had prevented them from migrating? The Qur'an rhetorically asks those who are in a state of inequity-literally, "zălimi anfusihim," which means "those who are unjust towards themselves"“Wasn't God's earth vast and expansive enough for you to migrate?” (Q. 4:97). Critically, according to the Qur'anic discourse, these individuals exist in a state of inequity, and their excuse for living in a state of injustice is that they are oppressed. The reason that these individuals live in a state of oppression is 
that they are powerless. This condition of powerlessness is what Quranic commentators refer to as a state of "istid'äf" - a state of oppressive injustice due to disempowerment. But per the Qur'anic discourse, the way to address this state of oppressive injustice and powerlessness is through migration.

Reading the Qur'anic verses in Surat al-Isrä' together with Surat al-Nis $\vec{a}$, there is a rather fascinating conjunction and a point of normative meeting between the idea of an earth that has been bestowed and granted to human beings in general, and the notion that mobility and travel is an essential or constituent element of human dignity. Oppression is a state in which one is powerless to enjoy the bounties (niam) of God's creation. A human being is entitled to dignity as a right bestowed by God upon creation, but this dignity is not simply theoretical or abstract; it has a concrete and material essence, or one can say, it is quintessentially deontological in meaning. The dignity of human beings is intimately interconnected with the opportunity to enjoy God's bounties and the freedom of movement and mobility. Accepting or acquiescing in oppression is iniquitous; it is as if passive acceptance of oppression leads one to be unjust towards oneself. Existing in such a state of injustice is morally unacceptable, and importantly, freedom of movement is necessary for the right to dignity and perhaps for a virtuous existence. Of course, the Qur'anic narrative goes on to state that men, women, and children who are truly weak and oppressed, and therefore, without any real means for escaping persecution are deserving of God's pardon because they are not blameworthy (Q. 4:98).

Before proceeding further, we should note that when it comes to the verses about migration in Surat al-Nis $\bar{a}$, a number of Quranic commentators concluded that this revelation was intended to address a particular set of historical events. Some Muslims who had converted at the time of the Prophet in Mecca had failed to join the Prophet and his followers in migrating to Medina. As a result, some of these converts to Islam ended up fighting on the side of the Meccan idolaters against fellow Muslims in the Battle of Badr. The revelation in Surat al-Nisa $\vec{a}$ was intended to blame those who placed themselves in the deplorable situation of having to fight on the side of idolaters against fellow Muslims by failing to migrate. If the Qur'anic discourse on migration is wedded to this specific historical circumstance, or in other words, if we read these verses as addressing those who converted to Islam but failed to join the Prophet in Medina and as a result, ended up joining the Battle of Badr on the wrong side; then these verses are substantially emptied of their normative content because they were intended to address an historical contingency that has already come to pass. But as a number of Qur'anic commentators have noted, even if the occasion for revelation was a specific historical event, by the terms of its own phrasing, the Qur'anic discourse on migration remains normatively pertinent. The Qur'anic narrative on migration is stated broadly and 
generally, and therefore, seems to be in a form that is non-contextual and to create a normative imperative for Muslims that would apply whenever there is an obligation to escape oppression or injustice (al-Rāzī 1990, 10-13; Quṭb 2007, 744-6).

We should note here that the issue of hijra or migration as a normative obligation in Islamic theology and law is complex and layered. Many jurists insisted that there is a permanent and lasting obligation upon every Muslim to migrate from the abode of unbelievers (dār al-kufr) to the abode of Islam (dār al-Islām). Accordingly, any sojourn to the abode of unbelievers must be temporary and wedded to a specific purpose. However, some reports attributed to the Prophet assert that the obligation to migrate was abrogated upon the defeat of Mecca and its entry into the Islamic fold (lā hijrata ba'da al-fath) (al-Hanbali $1996,114)$. In other words, according to this genre of hadith, migration was a temporary obligation that expired upon the defeat of the Meccans at the time of the Prophet. This counter tradition to the claimed obligation to migrate from the abode of unbelievers to the abode of Islam continued to be dynamic and viable, as many Muslims who lived in non-Muslim territories continued to seek legitimacy for their status. In other words, while some Muslim jurists insisted that Muslims should permanently reside only in the abode of Islam, other jurists negated this obligation contending that the duty to migrate expired shortly before the death of the Prophet. Nevertheless, apart from the polarizing debate about residing in the abode of Islam, the issue of wajjib al-hijra or the duty to migrate as a response to injustice, persecution, and oppression remained a tantalizing normative challenge throughout Islamic history. Many Muslim jurists argued that migration remains a normative duty until the end of time, but the obligation is to migrate and reside wherever Muslims may practice their faith freely or what they called "izhār al-dinn." Others argued that the duty is to migrate from the land of inequity (dār al-fisq) to wherever justice reigns (dār al-'adl). Especially in mystical Sufi orientations, the duty to migrate was interpreted in entirely spiritual and internal terms: hijra. In these spiritual theologies, hijra becomes an obligation to journey from and abandon the lower base and material self to the higher divine and supernal self. Hijra is not a physical residential status but a dynamic and perpetual process of spiritual elevation (Hassan 2013; Abou El Fadl 1994).

In addition to the normative idea of migration as a response to disempowerment and oppression, there are at least two other moral impulses within the Islamic tradition that are important to note in any discussion on Islamic ethics and migration. The two possible ethical norms in the Islamic tradition are wäjib al-diya $\bar{a} a$, the norm arising from the duty of hospitality, and mu'äkhā (brotherhood), which is an ethical example set when the Prophet built an effective social brotherhood between migrants of Mecca and the natives of 
Medina. I will comment on diyā $f a$ and mu'ākhà momentarily, but it is worth noting at this point that the Islamic tradition is replete with normative ethical possibilities or what one may describe as ethical potentialities and trajectories. The values of brotherhood and hospitality provide fascinating normative precedents that could have been developed by contemporary Muslims into a significant inspirational ideation or an aspirational moral direction. Hospitality and brotherhood, added to migration as a normative response to a state of powerlessness; all of that, plus the ethic of mobility as an essential component of human dignity, is a promising ethical baggage that could be seen as trajectories that could be employed in the purposeful construction of social and political virtues. I see the moral baggage inherited from the Islamic tradition as containing ethical impulses of virtue that could have been marshalled by contemporary Muslims into significant theological and ethical engagements with the modern discourses on human rights and dignity.

In my view, the Islamic tradition is replete with ethical potentialities that are embedded in complicated and layered historical narratives. These layered historical narratives do not contain a single or a unitary normative trajectory. Indeed, the historical narratives contain numerous normative trajectories that are often conflicting and that exist in tension with one another. Having said this, however, it is undeniable that in the midst of this tension, one finds soundly embedded ethical impulses or virtues, such as hospitality and brotherhood, that are as if an untapped potentiality. These ethical impulses have a moral trajectory or a possible normative power, but only if reclaimed and reconstructed into coherent epistemic interventions and practices in the modern world (Abou El Fadl 2014, iiii-iv). Relying on their own native moral and ethical resources, Muslims could have anchored themselves on virtues such as brotherhood and hospitality in making serious interventions in the contemporary discourses on migration and human rights (Hollenbach 2016; Wilson \& Mavelli 2016).

The reality, however, is that far from developing these normative impulses in their own tradition, Muslims in the contemporary, post-colonial age became rather obsessed with the apologetics of proving the essential compatibility between Islamic theology and law, and international law, but not going much beyond that. One often gets the impression that in Islamic normative discussions it as if the reconciliation between the Islamic tradition and the perceived demands of international law is a sufficient moral response to the challenges that confront the international community. There are numerous contemporary Muslim studies that seek to prove that Islamic norms are reconcilable with international legal standards. However, for the most part, in response to the growing problems of forced migration and displaced populations, contemporary Muslims have not leveraged their own ethical tradition in attempting 
to critique the limitations and exceeding the expectations of international law. Put bluntly, when it comes to forced migration and displacement, anchoring themselves on the moral thrust of their tradition, Muslims could have exceeded existing international law standards.

\section{The Inadequacy of International Law}

When dealing with forced migration and the displacement of human beings, international law continues to be largely inadequate. So, to argue the point that Islamic ethics or norms are simply consistent with international law is not much of a moral achievement. We know that the Refugee Convention and its accompanying protocol sets the standard for the non-refoulement of forced migrants, but we also know that its coverage is very limited. Article 33 in particular, which is the operative Article in much of the jurisprudence on migrants, provides the following:

No Contracting State shall expel or return ("refouler") a refugee in any manner whatsoever to the frontiers of territories where his life or freedom would be threatened on account of his race, religion, nationality, membership of a particular social group or political opinion.

The fact is that the Refugee Convention only addresses displaced individuals who have crossed an international border. The Refugee Convention does not cover internal displacement, i.e. people who have been displaced but have not crossed an international border. Moreover, the Refugee Convention simply obligates Contracting Parties not "to refoul," or turn back to the frontiers of territories, those individuals who are threatened on account of race, religion, nationality, social group or political opinion. The protected categories of race, religion, nationality, social group, or political opinion are legalistic and technical. For the most part, Contracting Parties to the Refugee Convention are not obligated to provide anything beyond the duty of non-refoulement. If the reason that someone is threatened falls out of the protected categories of race, religion, nationality, social group or political opinion, then states may, in fact, refoul or send back individuals to areas where their life and safety can be at risk. One should add that under The Convention Against Torture and Other Cruel, Inhuman and Degrading Treatment, there is an absolute prohibition against the refoulement of individuals who are at risk of suffering torture or any of the other enumerated harms. However, the protections afforded by the Torture Convention are narrow, and, in my opinion, are rather insufficient (McArthur \& Buchinger 2008). 
The obligations of Article 33 of the 1951 UN Convention Relating to the Status of Refugees (Refugee Convention) are severely constrained by the acknowledgement that States can refoul those individuals who threaten a country's national security or its perceived political stability. Thus, in international law, while we often talk about the ideals of voluntary repatriation, local integration, or safe resettlement to a stable country, the durable solutions continue to elude us. Ever since World War II, we have been talking about durable solutions for displaced refugees, whether it be groups of refugees such as Palestinians; Iraqis in Iran; Afghanis in Iran and Pakistan; Syrians in Turkey; Tibetans in Nepal; Filipinos in Malaysia; Angolans in Zambia; Sri Lankans in India; Mauritanians in Senegal; or Rohingyas in Thailand, India, Malaysia or Bangladesh. Solutions continue to elude us because the international jurisprudence that governs displaced individuals - while speaking of the ideals of voluntary repatriation, local integration or safe resettlement-does not have the power to obligate nations to, in fact, provide durable solutions.

What has been occurring is that for some 6o years, the world has taxed the already overtaxed Office of the United Nations High Commissioner for Refugees to provide ad hoc solutions to displaced populations around the world, often condemning people to life in camps with tents or makeshift communities, while countries continue insisting on the framework of national sovereignty as the overarching paradigm in dealing with and reacting to the crisis of displaced human beings around the world. One of the critical components missing in International Law is that there is no proportional obligation upon States that create the displacement of migrants, such as the United States or Russia, to take a proportional number of migrants for resettlement. In other words, a country like the United States can create an enormous amount of displacement in Iraq or Afghanistan, but wash its hands when it comes time to resettling refugees, simply throwing the obligation upon other countries such as Turkey, Pakistan, Kenya, Jordan, Lebanon, Chad, or according to the latest statistics, Germany. There are numerous problems with the International legal framework that continues to create a perpetual state of crisis in the world when it comes to dealing with forced migration, whether for political or economic reasons, and other displaced individuals. The problems of forced migration overlap with the exploitation of cheap labour and the trafficking in human beings in complicated and deeply troubling ways. We know that the 1951 Convention and ${ }_{1967}$ Protocol Relating to the Status of Refugees came into being post-World War II addressing largely European concerns in the Cold War era. The Refugee Convention protected specific categories of people that are able to be physically present in the territory or port of entry of the host country and that are then able to make an application for non-refoulement. But there is no international standard obligating countries that cause widespread displacement because of political, military, or economic policies pursued by such 
countries to take responsibility for the population of forced migrants. As it stands, the us, through the invasion of Afghanistan and Iraq, has created a serious refugee crisis. Russia has exasperated the refugee crisis in Syria through its persistent bombardment of populated areas. Saudi Arabia and the U.A.E. have created a refugee crisis in Yemen that is truly horrific, and Israel continues to act with absolute impunity towards the Palestinian refugee crisis. In all of these situations, while there are humanitarian and human rights standards that do apply, and that do condemn offending countries for their acts of aggression, the international law response to forced migration and displacement remains weak at best (Martin \& Weerasinghe 2014; Cubie 2017). Ideally, if a country, through its military policies or otherwise, causes forced migrations and displacements, then such a country at a minimum should be held financially accountable for compensating the displaced populations, and should be responsible for providing a safe haven and the safe resettlement of the populations it displaced. Otherwise, powerful countries and governments through aggressive military, political, or economic policies will continue to exacerbate the ongoing refugee crisis in the world. Some states and governments are more responsible than others for creating the current refugee crisis and it is ethically defensible to expect that these states and governments bear the greater burden of solving this crisis (Duarte et al., 2017).

\section{3}

\section{Islamic Ethics and Migration}

Returning to the issue of Islamic ethics and migration, I think it is fair to say that the Muslim contribution in this ongoing state of crisis has been largely muted and ineffective. In fact, there has been a drift away from the Islamic tradition, which could have enriched international discourses by tapping into the theology of mu'a $\bar{k} h \bar{a}$ (brotherhood), or diya $\bar{a} f a$ (hospitality), or hijra (migration) as a response to istid' $\bar{a} f$ (oppression). Indeed, beyond these under-developed normative impulses, there is a well-embedded moral concept of refuge and protected status in the Islamic tradition (Zamān 2017, 19-43; Shoukri 2010; Arnaout 1987). The Qur'anic text states: "And if any of the unbelievers seek asylum with you (istajäraka), grant it to him ( $f a-$-ajirhu $)$ until he hears the Word of God, then escort him to a place where he is secure for they are people without knowledge." (Q. 9:6). Classical Muslim jurists developed extensive discussions on the rights of the musta'man (person enjoying a protected status) and the status of amān (pledge of security or safe conduct) (Bashir 2018, 236-9). Whether asylum can be elevated to the status of an entitlement or right as opposed to a solemn and perhaps sacred privilege is anchored in the ethical tradition of ijāra as opposed to the jurisprudence of amān. The mujjar or the 
recipient of ijära was a person who enjoyed a protected status by virtue of a social status as opposed to political or business interest. Although the practice of ijära in the Islamic tradition calls for more extensive historical investigations, the ethical impulse is poignantly represented in a number of traditions from the time of the Prophet. Umm Hanī bint Abì Țālib, the Prophet's cousin, made a grant of ijära to unbelievers who were visiting Medina. As the narrative goes, she had a rather public and heated dispute with 'Alī ibn Abī Ṭâlib, her brother, about the validity of this grant of protection. The dispute was taken to the Prophet who ruled in favor of Umm Hanī, making what would become a famous statement providing that the grant of ijära by a single Muslim is binding upon all Muslims. In perhaps an even more famous incident, the Prophet's daughter Zaynab stood up in the mosque in Medina after the morning prayers, and announced that she had given an ijāra to her ex-husband, the idolater Abū al-Āṣ ibn al-Rabi's, who apparently was present in her house at the time. The Prophet stood up and announced that this is the first that he has heard that Ibn al-Rabī' was in Zaynab's home, and that Zaynab had granted him protection. However, the Prophet announced that as Zaynab had granted Ibn al-Rabī this status, her ijära must be respected. Reportedly, on this occasion, the Prophet made a proclamation that has for long engaged and stimulated the ethical thinking of Muslims. Reportedly, the Prophet said words to the effect that the commitments of one Muslim is binding upon all (dhimmatu al-muslimin wăhida), and that a grant of protection by the weakest in society is binding upon even the strongest (Al-Jawzī 1992, 257; Al-Ṭabari 1387, 348; Guillaume 1955, 317).

The above mentioned traditions on ijāra are often cited in classical juristic discussions on amān or the granting of safe conduct. In fact, relying on the Zaynab and Ibn al-Rabī precedent, Hanafí jurists and some others held that a guarantee of safe conduct can be granted by any member of society and it is valid and effective against all (Al-Dawoody 2011, 133). However, one suspects that the tradition of ijära connoted a moral virtue of hospitality and kindness towards strangers or aliens that is broader in its ethical import than amān. The Quranic verse quoted above advising Muslims to grant unbelievers safe conduct so that they may hear the word of God (Q. 9:6) was interpreted by Muslim jurists as the legal basis at the heart of the jurisprudence of amān. However, this verse uses a derivative of the word j.w.r. which means to protect, aid, or honor. In the Muslim tradition, the word jiwār has a diverse set of meanings that contain far reaching moral implications (Ibn Manzūur 1997, 414-5). A mujāwir was a client who adhered to the service of a sanctuary, and such clients enjoyed a sacrosanct status (Bashir 2018, 50; Al-Ghunaimi 1968, 11-13). Servants of shrines or Sufi lodges were known as mujāwirs (mujāwir sg./ mujāwirun pl.) and at least until modernity this class of individuals enjoyed a protected status. Moreover, the rights of neighbors, or neighborly rights and 
privileges, is known as haqq al-jiwär or haqq al-jär, which continues to be an important normative category at least in non-urban or less urbanized Muslim cultures.

The ethical impulses that one finds permeating the Islamic tradition if transformed into inspirational ideological concepts, or even beyond this, if articulated into systematic legal conventions and treaties between Muslim nations, could have coalesced to become an influential institution in modern international practice. The concept of freedom of movement as a necessary element for upholding human dignity; the right to escape oppression through migration; this coupled with the traditions of hospitality and brotherhood (which is analogous to the French concept of fraternity); in addition to neighborly rights and the sanctity of visitors create a powerful normative universe that could become the basis of inspired activism and practice. To the extent that ideals can inspire and influence human activity, one can rightfully expect that Muslims tap into their own rich normative tradition to improve upon the universal standards that humanity sets for itself. Unless one believes in strict historical materialism and does not credit ideas with the ability to at least in part direct and shape human activity, I think we are justified in asking whether contemporary Muslims have been able to co-opt, adapt and negotiate their own moral traditions in helping to shape the humanitarian standards that exist in the world today. I think it is fair to say that the entire genre of "human rights thinking," or "thinking about virtue ethics" is premised on an aspirational modality. All thinking about human rights standards as well as the discipline of virtue ethics seeks to change conduct through persuasion and influence. If one abandons the task of hoping to persuade and influence the way people conduct themselves, then there would be no point to scholarly narratives beyond the strictly descriptive and non-evaluative. However, because I do believe that ideals do matter, in much the same way that ethics and legal standards matter, I do not believe that it is overly naïve to hope that Muslims would be able to tap into the power of the ethical trajectories embedded in their own tradition to achieve a greater measure of justice for the human community.

Before commenting on Muslim countries in the modern context, I should briefly address the issue of dār al-Islām versus dār al-kufr or dār al-harb (abode of Islam as opposed to the abode of infidels or the abode of war). Even before the rise of IsIs and its so-called Caliphate state, some modern commentators have continued to argue that the major obstacle to Muslims embracing an inclusivist participatory paradigm towards the world community is their persistent influence of the polarity of the abode of Islam, which exists in opposition to the abode of infidels or the abode of war (Lewis 2006). According to this point of view, it is the continued impact of this dichotomous and exclusivist perspective upon Muslim thinking that has obstructed the ability of Muslims to make normative commitments to democracy, human rights and humanitarian 
standards. Although this is a larger issue that cannot be adequately addressed in this context (Abou El Fadl 2014, 203-270), I will say that I do not believe that the historical legacy of dār al-Isläm or abode of Islam versus any other abode as a significant obstacle to the development of a moral response to the issue of displacement in the modern age. For the most part, I do not see it as a significant obstacle because I think that dār al-Islām is an ambiguous category, endlessly discursive in nature, and endlessly negotiable. In my reading of the tradition, much of what is written on dār al-Islām in the classical period correlates to or parallels the medieval discourses on Christendom, or in the case of Judaism, the discourses on Jews and Gentiles (MacCulloch 2014; Hall 1997). There were historically embedded ideological and political categories that helped pre-modern subjects negotiate the realities of their existence. However, those who study the history of the Crusades and the complex and non-dogmatic Muslim response to the Crusades, and those who study the rise and fall of Muslim dynasties and the rise of the Ottoman Empire ought to be struck by the historically discursive and persistently negotiable nature of a designation such as dār al-Isläm. The least one can say is that it was no less negotiable and no less resistant to broad generalizations than the history of the idea of Christendom or the categories of Jew and Gentile. Moreover, one should note that Muslims have found it sociologically easy to migrate from Muslim countries to non-Muslim countries if that meant attaining a greater degree of dignity and a greater degree of justice. In the modern age, while Saudi muftis continued to issue responsa, prohibiting Muslims from migrating or residing in the abode of infidels, and by infidels they mean the West, such fatwas do not seem to have made much of an impact in stemming the flow of Muslim migrants to Western countries. The alleged or presumed continued impact of the abode of Islam upon the Muslim mind is nothing but a projected myth—dār al-Isläm has become a nuanced, highly problematized category in the Muslim mind and has been so for centuries. It is disingenuous to suggest that dār al-Islām has survived as a coherent category not only through the vestiges of medieval history, but also colonialism, World War I and II, the Arab Revolt, the breakup of the Ottoman Empire, the rise of nation-states, and even dramatic and traumatic modern events such as the Iraq/Iran war and many others.

Overcoming the hold of a stereotypical dichotomous division of the world over the Muslim imagination is not the challenge that Muslims must overcome in the modern world. The real challenge is for Muslims to re-interrogate and rediscover their own rich tradition and adapt it to meeting the moral challenges of the age. For instance, the very idea of dār al-Isläm coupled with the Quranic narrative describing Muslims as but a single nation or umma $(\mathrm{Q}$ 21: 92; Q 23:52) could have inspired Muslims to overcome, or at least mitigate the 
worst pitfalls of nationalism, ethnocentrism, and racism. Muslims could have co-opted and leveraged the moral impulse behind dār al-Isläm into an ethic of civility, fraternity, and decency towards one another. Indeed, the utter failure of projects such as the Muslim World League in mitigating the draconian harshness of national territorial borders or in alleviating the suffering of displaced people-especially displaced Muslim populations in other Muslim countries, is living proof of the ineffectiveness of a concept such as dār alIslām upon the modern Muslim imagination. I do not say this because I wish to deconstruct the concept of dār al-Isläm as perhaps intimately interconnected to the notion of a single umma or indeed to a Muslim fraternity or mu'äkhā. Rather, I say this because it does take a certain amount of incredulous mythological thinking to continue ignoring the socio-historical realities, and insist that Muslims do in fact adhere to conceptual categories found in medieval texts written for a different time and place.

Unfortunately since the colonial era, Muslim countries have first emulated Western countries in adopting vulgar forms of stark nationalism in which they drew strict territorial boundaries vis-a-vis one another. But then Muslim countries lagged behind Western countries that have reached a point of what some have called a "post-nationalist paradigm." In other words, the West has successfully managed to reach a post-nationalist reality in which they diluted the national borders between various Western countries. It is true that this post-nationalist reality is racially and ethnically contingent- the rise of the ideology of a unified Europe was accompanied by the rise of the racist thesis of the clash of civilizations and the triumphalist, albeit racist, thesis of the "European miracle" and the West against the rest (Schmidt 2004; Pagden 2009; Jones 2003). But the reality is that one can be an American citizen and travel all over Europe without a visa, and one can also be a British citizen and travel all over Europe without a visa. Moreover, it has become as if an article of faith that an act of aggression against a single Western country is an attack against the rest. It is not an exaggeration to say that in the contemporary world, despite the differences in languages, cultures, economic systems, and religious beliefs, there is a basic and fundamental moral unity of purpose and fate among White Europeans. Trying to make sense of this post-nationalist unity of fate and purpose, some have even resorted to describing it in terms of the largely incoherent category of the "Judeo-Christian tradition," as a distinctive sociologically and anthropologically shared reality (Cohen 1971; Topolsky \& Nathan 2017). The irony is that while orientalist scholars continued to refer to the Muslim world as a single unit and to attribute to this unit a tribal-like mentality of allegiance and affiliation, it is really the White Western world that developed a common sense of solidarity and cultural affinity. Whether one accepts that the Western 
sense of solidarity is in reality racially based or not, many believe that the West has formed a common sense of purpose over shared normative values such as democracy, liberty, freedom of speech and the like.

Muslims meanwhile have deconstructed the concept of umma, and deconstructed the concept of brotherhood (ukhuwwa), and largely ignored their tradition of diyāfa or hospitality in rather ironic and paradoxical ways, to become more zealously defensive of the paradigm of nationalism and nationalist borders, even amongst Muslim countries themselves in ways that have made them lag morally behind Western countries. We should recall in this context the $k a-$ fala system in Gulf countries that continues to be directly responsible for very widespread abuses against labour (Human Rights Watch 2009). Far from being consistent with the ethics of diyāfa, mu'äkhā, or ijära, the kafala system has institutionalized structural abuses against migrants and displaced people. Some countries such as Saudi Arabia and the U.A.E. have become habitual offenders in the unconscionable practices of human trafficking and modern-day slavery (Mahdavi 2009). Moreover, in oil-rich Gulf countries, the kafala system has become inextricably interwoven with a racist outlook in which the Western White man occupies the upper height of the racial hierarchy. In oil-rich Gulf countries there is a strict racially stratified cultural outlook in which the White European and American male occupies a distinct place of superiority and privilege. It is as if many Muslim countries imported and internalized the racial outlooks of their former White colonizers in ways that have effectively hampered their ability to rehabilitate and develop their own natively-based ethical contributions towards migrant workers and displaced human beings.

If one wants to understand the hold of territorial nationalism over the Muslim imagination, one needs to go no further than evaluating the status of the Hijaz since it came under Saudi control in the early 2oth Century. The Hijaz, the place of the holy cities of Mecca and Medina, is a cultural and moral heritage for all Muslims of every school, sect, and creed. Yet instead of having some semi-independent sacred status such as the Papal states or a status of shared Muslim governance, the Hijaz is treated strictly from within a territorial nationalist paradigm. It is considered part of the nationalist territory of the sovereign state of Saudi Arabia, and it would be absolute sacrilege for any Muslim country to demand a role in the shared governance of the holy sites (Abou El Fadl 2014). My point is that the status of the Hijaz is emblematic of the fact that it is not the native ideals of dār al-Isläm or the single umma that holds sway over the modern Muslim imagination but the imported principles of vulgar territorial nationalism. Some of the nationalist practices of Muslim countries have been nothing short of shocking to the conscience. For instance, the way Egypt has dealt with the displacement of Bedouins in Sinai or the Palestinians 
of Gaza, or the way that the United Arab Emirates and Saudi Arabia have dealt with displacement in Yemen is a course of a pattern of practice that is not just offensive to modern concepts of humanitarian law and human rights, but even to the most basic principles of the Islamic tradition. The conduct of the Egyptian, Emirati, and Saudi governments towards displaced and destitute Palestinians and Yemenis respectively evidences not just a gross disregard of human rights and humanitarian standards but also the flouting of Islamic ethical precepts with rather disquieting impunity.

\section{4}

\section{Conclusion}

We should not end on a despondent note. The aspiration is that Muslims would investigate their own moral tradition to help construct humanitarian paradigms that elevate international moral trajectories rather than simply acquiescing and rubber-stamping vague doctrines produced by nation-states in search of their own national interests. The Muslim tradition is replete with powerful virtuous ethical impulses that could make substantive contributions to the field of forced migrants and displacement. Among these ethical impulses are critical concepts of counter-istid'a $a$ - countering oppression and powerlessness through mobility and accessibility, first and foremost between Muslims themselves; and then second, between Muslims and "the other"; as well as the ethics of $m u^{\prime} \bar{a} k h \bar{a}$ (brotherhood), diya $\bar{a} a$ (hospitality), and ijära (asylum). These are ethical concepts that could easily find common ground with other religious and faith-based traditions, in a way that challenges and elevates, rather than simply apologetically rubber-stamping modern international law. It is perhaps not too audacious to hope that Muslims take their own ethical tradition seriously enough by deploying it in the service of alleviating and removing human suffering, especially when it comes to what the Qur'an poignantly describes as al-ghärimin wa fì sabïli Allah wa ibn al-sabïl (those who are burdened with debt and the wayfarers in need) (Q. 9:6o).

\section{Acknowledgements}

I am very grateful to my wife, Grace Song, and my student and research assistant, Zezen Zaenal Mutaqin, for their invaluable feedback and assistance. 


\section{Bibliography}

Abou El Fadl, Khaled. 1994. "Islamic Law and Muslim Minorities: The Juristic Discourse on Muslim Minorities from the Second/Eighth to the Eleventh/Seventeenth Centuries." Islamic Law and Society 1(2): 141-187.

Abou El Fadl, Khaled. 2014. Reasoning with God: Reclaiming Shariah in the Modern Age. Maryland: Rowman \& Littlefield.

Al-Dawoody, A. 2016. Islamic Law of War: Justifications and regulations. New York: Palgrave Macmillan.

Al Ghunaimi, M.T. 2013. The Muslim Conception of International Law and the Western Approach. Springer.

Arnaout, G.M. 1987. Asylum in the Arab-Islamic Tradition. Geneva: Office of the United Nations High Commissioner for Refugees, International Institute of Humanitarian Law.

Bashir, Khaled Ramadan. 2018. Islamic International Law: Historical Foundations and al-Shaybani's Siyar. S.l.: Edward Elgar Publishing.

Cohen, A.A. 1971. The Myth of the Judeo-Christian Tradition: and other Dissenting Essays. New York: Schocken Books.

Cubie, Dug. 2017. The International Legal Protection of Persons in Humanitarian Crises: Exploring the Acquis Humanitaire. Oxford: Hart Publishers.

Duarte, Melina, Kasper Lippert-Rasmussen, Serena Parekh and Vitikainen, Annamari. 2018. Refugee Crisis: The Borders of Human Mobility. Taylor \& Francis.

Guillaume, A. 1955. The Life of Muhammad: A Translation of Ishāà's Sirat Rasūl Allāh. Oxford: Oxford University Press.

Hall, D.J. 2002. The End of Christendom and the Future of Christianity. Eugene: Wipf and Stock Pub.

al-Ḥanbalī, Abū al-Faraj ibn Rajab. 1996. Fatḥ al-Bārī Sharh Șaḥịh al-Bukhārī. Vol. 1. Maktabat al-Ghurab'à.

Hassan, Said Fares. 2013. Fiqh al-Aqalliyāt, History, Development and Progress. New York: Palgrave Macmillan.

Hollenbach, David. 2016. "Religion and Forced Migration." In The Oxford Handbook of Refugee and Forced Migration Studies, edited by E. Fiddian-Qasmiyeh, G. Loescher, K. Long, and N. Sigona. Oxford University Press.

Human Rights Watch. 2009. "The island of happiness": Exploitation of migrant workers on Saadiyat Island, Abu Dhabi. New York: Human Rights Watch.

Ibn Manzūur, Al-Imām. 1997. Lisān al-'Arab. Vol. 2. Sader.

al-Jawzī, Jamāl al-Dīn Abū al-Faraj 'Abd al-Raḥmān ibn 'Alī Ibn. 1992. Al-Muntazam fì Tārīkh al-Umam wa-l-Mulūk. Vol. 3. Beirut: Dār al-Kutub al-'Ilmiyya

Jones, Eric. 2003. The European Miracle: Environments, Economies and Geopolitics in the History of Europe and Asia. Cambridge University Press. 
Jones, R. 2017. Violent Borders: Refugees and the Right to Move. Verso Press.

Lewis, B. 2006. What Went Wrong?: the Clash between Islam and Modernity in the Middle East. Harper Perennial.

MacCulloch, D. 2014. Christianity: the First Three Thousand Years. Penguin Books.

Mahdavi, P. 2011. Gridlock: Labor, Migration, and Human Trafficking in Dubai. Stanford University Press.

Martin, S.F and S. Weerasinghe. 2014. Humanitarian Crises and Migration: Causes, Consequences and Responses. Routledge.

Mavelli, Luca and Erin Wilson. 2017. "The Refugee Crisis and Religion beyond Conceptual and Physical Boundaries." In The Refugee Crisis and Religion: Secularism, Security and Hospitality in Question, edited by L. Mavelli and E. Wilson. Rowman \& Littlefield International.

Nathan, E. and A. Topolski. 2017. Is there a Judeo-Christian Tradition? A European Perspective. Berlin de Gruyter Mouton.

Nowak, Manfred and Elizabeth McArthur. 20o8. The United Nations Convention against Torture: A Commentary. Oxford University Press.

Pagden, Anthony. 2009. Worlds at War: The 2500 Year Struggle Between East and West. Random House.

al-Rāzī, Fakhr al-Dīn. 199o. Al-Tafsìr al-Kabìr. Vol. 11. Beirut: Dār al-Kutub al-'Ilmiyya.

Quțb, Sayyid. 2007. Fì Ziläl al-Qur'an. Vol. 2. Cairo: Dār al-Shurūq.

Schmidt, Alvin. 2004. The Great Divide: The Failure of Islam and the Triumph of the West. Regina Orthodox Press.

Shoukri, A.M. 2011. Refugee Status in Islam: Concepts of Protection in Islamic Tradition and International Law. I.B. Tauris.

al-Ṭabarī, Ibn Jarīr. 1387. Tārīkh al-Ṭabarī. Vol. 2. Egypt: Dār al-Turāth.

Zaman, T. 2017. Islamic Traditions of Refuge in the Crises of Iraq and Syria. New York: Palgrave Macmillan. 